\title{
The Customer Satisfaction in Buying Product by using Media E Commerce
}

\author{
Ravindra Safitra Hidayat
}

\begin{abstract}
The study aimed to identify the purchase of products through social media marketing e commerce and price of, customer satisfaction to know the impact of customer satisfaction, purchase of the decision to understand social marketing through e commerce, purchase of the decision and to know the customer satisfaction through direct impact of the decision in. online purchases. The result of this research was social marketing through $e$ commerce on customer satisfaction is positive and significant. Influences the price of customer satisfaction is negative and significant, the influence of customer satisfaction in the purchase of the decision on the line is positive and significant, the influence of social marketing through e commerce of the decision to buy is positive and significant, the purchase price of the decision is negative and significant.
\end{abstract}

\section{Background}

In the era of globalization as now it is competition in the business world to be very strict. The company compete with each other in compete to maintain a venture to be tough in the competition is fierce. Create new customers and retain customers who are long and to increase the volume of sales with the marketing strategy through the internet is the goal the company.

It has since built a the internet is something that is already is not going to be a need for at the present time, but have become weak and helpless an orderly lifestyle and dependability in each of the four people. The development of this very moment become more and more fast paced growth can be after of the internet started can be accessed via cellular phone and come up with to which the name is a smart phone from apple or a phone smart. Where there are a lot as the facilities that are given to community groups in a smart phone reflected the bank sound assets, chat, email i have got to , browse, as well as the facilities social media

E-commerce is the process of purchasing, sale or the exchange of goods and services and information via computer network including the internet.For some big firms ecommerce be a part in the development of, marketing, the sale of , delivery, and the payment of services customers with the support of the business partner of a network of around the world [1].

\section{Theoretical Framework}

\subsection{Understanding of social marketing}

Based on the definition of the experts, social marketing was essentially an application commercial marketing

Revised Manuscript Received on July 05, 2019.

Ravindra SafitraHidayat,

Faculty of Economics and Business, Universitas Budi Luhur,

ravindra.safitra@budiluhur.ac.id strategies to sell idea in order to change a society, especially in the management which includes, analysis, planning implementation and supervision.

The application of social marketing is one part of a framework called "doing great by doing good" [2]. Six choices for doing good are cause promotions, cause related marketing, social marketing, corporate philanthropy, community volunteering. Social marketing is an effort to support the implementation and / or change of community behavior

The yuan in encyclopedia of information science and technology said e-commerce is the use of computer network to communicating business and commercial transaction .Then on the website e-commerce net, e-commerce defined as an activity to sell merchandise and / or services over the internet.All components involved in business practical applied here, as customer service, products that are available, payment methods, security for products, the promotion and forth

According [3] quoted from book marketing management said that consumer satisfaction is feeling glad or disappointed someone who appears performance after comparing products (the) thought to expected performance.

\subsection{Understanding of Trust}

Consumer confidence is defined as the willingness of one of the parties to accept the risks of other parties based on hope that other parties to take action for the important, who believe in regardless of ability to supervise and control the act of parties believed [4].

\subsection{Understanding of Price}

States that "Prices can be used as an indicator of substitute for product quality, with high-value products that can be viewed positively by certain market segments [5] States "Price is the amount of money one must pay to obtain the right of use the product. Price sometimes serves as a signal of quality. A product prices too low might be perceived as having low quality" [6].

\subsection{Understanding of Product Quality}

Understanding Product Quality According ${ }^{7}$ product quality is the ability of an item to provide results or performance that is even more than exceeds, whereas According to Kotler \& Armstrong (2011) [7], product quality is the product's ability to display its function, this includes the time of use of the product, reliability, convenience, use and improvement, and other values. 


\subsection{Definition of Consumer Purchasing Decisions}

Consumer Purchase Decisions according to Sudaryono (2014) are "a selection of actions from two or more alternative choices [8]." If someone is faced with two choices, namely buying and not buying, then he is in a position to make a decision. In fulfilling their life needs, a consumer must choose the products and services to be consumed [9].

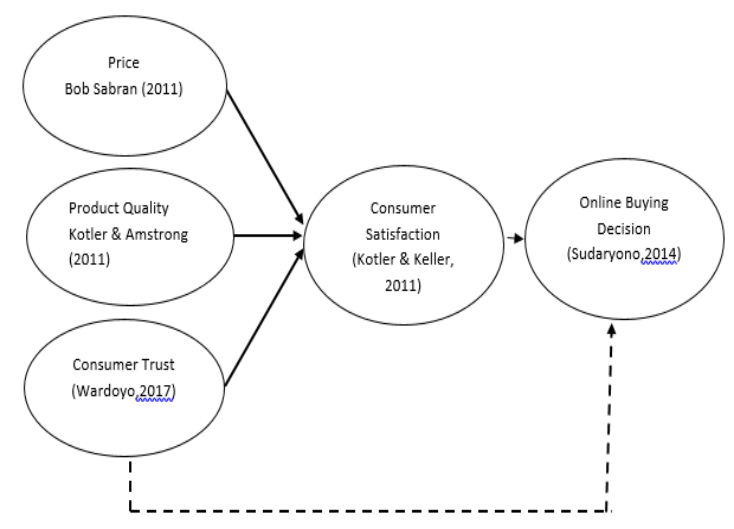

Figure 1:Research Framework

\subsection{Formulation of Research Hypotheses}

H1: Price has a positive and significant effect on customer satisfaction

$\mathrm{H} 2$ : Product quality has a positive and significant effect on customer satisfaction

H3: Consumer trust has a positive and significant effect on customer satisfaction

H4: Prices have a positive and significant effect on the decision to buy online

H5: Product quality has a positive and significant effect on the decision to buy online

H6: Consumer trust has a positive and significant effect on buying decisions online

\section{Research methodology}

This type of research is explanatory research using a quantitative approach. According, research according to the level of explanation is research that intends to explain the position of the variables studied and the relationship between one variable and another variable.

In addition, this research is intended to test the hypotheses that have been formulated previously. In the end the results of this study explain the causal relationship between variables through hypothesis testing.

\section{Result}

\subsection{Research Model Coefficients}

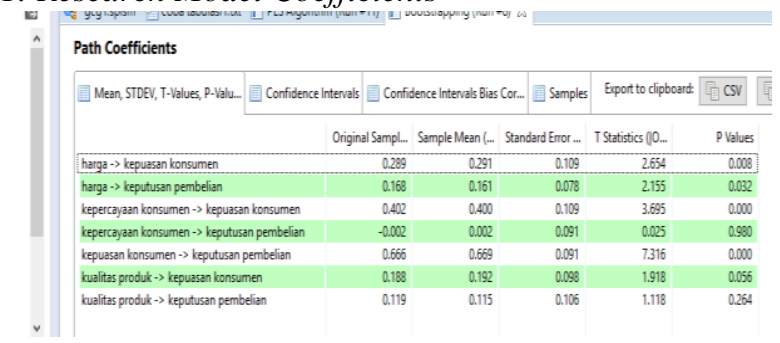

The results of the T-test (2-tailed) with a 5\% significance level as shown in the table above show that the effect of prices on consumer satisfaction and prices on purchasing decisions, consumer satisfaction with purchasing decisions, proved significant because each had an empirical $t$ value above 1.9852 that is and has a significance value (P Value) $<5 \%(0.05)$, whereas consumer confidence in product quality on customer satisfaction and product quality on purchasing decisions and quality is not proven significant because each variable has an empirical $t$ value above table value of 1.9852 and significance $(\mathrm{P}$ Value) $>5 \%(0.05)$

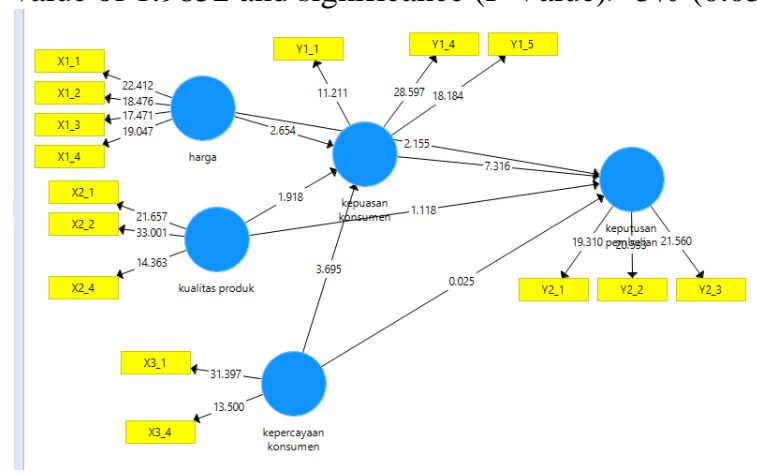

\subsection{Interpretation of Research Results}

Hypothesis testing using the PLS-SEM method is broadly divided into two stages, namely the analysis of the measurement model and the structural model. Analysis of measurement models can be said as an analysis of validity and reliability, while structural model analysis is used to test hypotheses.

a. The effect of prices influences consumer satisfaction

From the results of the price variable analysis has a significance value of 0.008 below 0.05 , it can be interpreted that prices have a positive and significant influence on customer satisfaction. Where the higher the price set by the company for a product, the consumer will be satisfied.

b. Effect of product quality on customer satisfaction.

c. The influence of consumer confidence affects consumer satisfaction.

d. Effect of prices on decisions to buy online.

e. Effect of product quality on online buying decisions.

f. The influence of trust influences the decision to buy online.

\section{Conclusion}

1. The effect of price influences consumer satisfaction From the results of the price variable analysis has a significance value of 0.008 below 0.05 , it can be interpreted that prices have a positive and significant influence on customer satisfaction. where the higher the price set by the company for a product, the customer will.

2. Effect of product quality on customer satisfaction

3. The influence of consumer trust affects consumer satisfaction

4. Effect of prices on decisions to buy online

5. Effect of product quality on online buying decisions

6. The effect of trust influences the decision to buy online 
Ethical clearance - Not required

Source of funding- Self

Conflict of Interest - Nil

\section{References}

[1] Saragih, H., \&Ramdhani, R. (2012).Influence of Customer IntentionIn Online ShoppingReturn to MediaSelling Forum Information TechnologyBuy (FJB) Kaskus. Journal ofInformation Systems, 8 (2), 100-112

[2] Kotler, Philip dan Kevin LaneKeller. Marketing Management $15^{\text {th }}$ Edition, Pearson EducationLimited,2015

[3] Kotler, Philip dan Kevin LaneKeller. Marketing Management $13^{\text {th }}$ Edition, Jakarta: Erlangga, 2009.

[4] Wardoyo1 Students, Intan Andini2, Journal of Resource Management Economics Vol. 19, No. 1, June 2017

[5] Sangadji, Etta M., Sopiah. 2013. Consumer Behavior. Yogyakarta: ANDI.

[6] Del I. Hawkins, David L. Mothersbaugh. Consumer Behavior: Builiding Marketing Strategy, McGraw-Hill Irwin, 2010

[7] Kotler, Philip and Kevin Lane Keller. Marketing Management. Translation by Bob Sabran. Jakarta: Erland 2011

[8] Sudaryono. 2014. Consumer Behavior inMarketing Perspective. Jakarta: Scholar Science Lanterns

[9] Sugiyono. 2016. Quantitative, Qualitative, and R \& D Research Methodology. Bandung: CV Alfabeta 